\title{
Perspectivas em Ciência da Informação: 15 anos testemunhando e construindo a Ciência da Informação na ECI/UFMG e no Brasil
}

Ao final de 2010 a revista Perspectivas em Ciência da Informação (PCI) completou quinze anos de existência. Foram 35 números publicados neste período e quatro números especiais. Além de artigos com resultados de pesquisas e discussões teóricas, PCI publicou também importantes traduções, relatórios, balanços, registros históricos e resumos de teses e dissertações.

Como se espera de um periódico científico, PCI atuou como instrumento de legitimação e consolidação científica do campo da Ciência da Informação, não apenas como testemunha (sendo veículo da publicização dos diferentes conteúdos que estruturam o conhecimento científico produzido), isto é, registrando as mudanças e a evolução da área, mas também como um protagonista ativo, na medida em que, em diversos momentos, por meio dos trabalhos publicados e pela maneira de os publicar, ajudou também a consolidar um determinado percurso para a área de Ciência da Informação no Brasil.

Tal movimento pode ser verificado na própria concepção da revista. Surgida em substituição à pioneira Revista da Escola de Biblioteconomia da UFMG, criada ainda no início da década de 1970, PCI se inseria num conjunto de amplas mudanças vivenciadas na década de 1990, na então Escola de Biblioteconomia da UFMG: a criação do curso de Aperfeiçoamento em Gestão de Recursos Informacionais, por meio do qual se institucionalizou o atual Núcleo de Estudos em Informação Tecnológica e Gerencial (Niteg), em 1993; a mudança de nome do curso de Mestrado, de Biblioteconomia para Ciência da Informação, em 1991, sendo criado o doutorado em Ciência da Informação em 1996; a mudança nos nomes dos departamentos da Escola (o "Departamento de Bibliografia e Documentação" passa a chamar-se "Departamento de Organização e Tratamento da Informação" e o "Departamento de Biblioteconomia" passa a designar-se "Departamento de Teoria e Gestão da Informação"). Por fim, a mudança do nome da Escola, para Escola de Ciência da Informação, no ano 2000, consolidou definitivamente uma nova visão da identidade da área e da instituição.

Essas várias mudanças de denominações representam uma importante sinalização sobre a composição do campo científico no qual a Biblioteconomia é um ator importantíssimo, embora não o único. 0 
projeto de Ciência da Informação defendido pela ECI/UFMG e desenvolvido através da atuação de seus professores, caminhou cada vez mais em direção a um alargamento de fronteiras privilegiando temáticas como a Gestão da Informação, os estudos em Informação, Cultura e Sociedade, além dos aspectos relativos à Organização e Representação da Informação. Nos últimos três anos, esse processo se completou com a criação dos cursos de graduação em Arquivologia e Museologia compondo, portanto o quadro de um amplo projeto de Ciência da Informação para o Brasil.

Logo em seu primeiro número, verificou-se a vocação de PCI para a definição e construção da Ciência da Informação no Brasil, com a tradução de um importante artigo de Tefko Saracevic sobre a história e a identidade da Ciência da Informação, além de vários artigos discutindo o estatuto científico da área e o conceito de informação. No número seguinte, além dos vários artigos, e apenas como exemplo da importância dos trabalhos publicados, destaca-se uma resenha do livro "A Ciência da Informação", de Yves Le Coadic, então recém-lançado no Brasil e que se tornou uma bibliografia obrigatória do campo ao defender a Ciência da Informação como uma disciplina científica, unificada e agregadora, de diferentes campos profissionais.

No ano 2000, um volume especial de PCI foi inteiramente dedicado às comemorações dos 50 anos da escola - constituindo-se num importante documento sobre a evolução desta instituição e também da área. Foram publicados textos refletindo sobre a graduação em Biblioteconomia, a pós-graduação em Ciência da Informação, sobre o Núcleo de Informação Gerencial e Tecnológica, além de relatos históricos sobre a Escola e o campo, bem como anexos com listas relativas a todo o pessoal da Escola e às teses e dissertações defendidas. Destaca-se ainda, neste número, o importante documento que consistiu no fundamento para a mudança do nome da Escola. Nele, é analisada a nova realidade da área, os novos contextos de atuação profissional e as novas possibilidades de intervenção a partir das tecnologias digitais, além se ser já anunciada a pretensão da escola em sediar outros cursos de graduação na área de Ciência da Informação. Destaca-se na argumentação, sobretudo, a ideia de um "novo paradigma" no campo - ideia traduzida tanto pela nova expressão "Ciência da Informação" como pelo significado de sua relação com a Biblioteconomia. O novo nome sinaliza a abrangência e a complexidade que se deseja imprimir à realidade da escola. Há ainda, neste texto, uma relevante análise da realidade da área em outros países, de forma a se produzir um diálogo entre as realidades brasileira e mundial.

Nos anos seguintes, PCI se torna um espaço fundamental de consolidação desta perspectiva anunciada, por meio da pluralidade temática dos artigos publicados, além da diversidade de procedência institucional dos autores. São publicados números temáticos, como o volume 5, número 2, de 2000, sobre a informação na indústria brasileira, 
e números especiais, como o de 2003, sobre a informação na sociedade da informação. Ao final de 2005, um editorial do professor Paulo da Terra Caldeira anunciava que PCI passaria a adotar o Sistema Eletrônico de Editoração de Revistas (SEER), apoiando as iniciativas de acesso aberto ao conhecimento científico. Neste mesmo editorial, já constava a boa notícia da mudança na periodicidade da revista, de semestral para quadrimestral.

Um outro exemplo de tradução importante publicado pela revista foi o artigo "O conceito de informação", de Rafael Capurro e Birger Hjorland, autores de prestígio internacional que foram, inclusive, conferencistas na abertura dos ENANCIB de 2003 e 2007, respectivamente. Também importante foi o número especial publicado em 2009 com alguns dos trabalhos selecionados e revisados de um colóquio ocorrido no Rio de Janeiro de uma rede franco-brasileira de Ciência da Informação (a Rede Mussi), marcando importante passo na internacionalização da pesquisa brasileira.

Em 2008, o terceiro número da revista trouxe outro documento a ser destacado: o texto de fundamentação da mudança no curso de graduação em Biblioteconomia e de criação do curso de Arquivologia, ambos inseridos num projeto geral de reformulação da graduação da ECI/UFMG em torno da ideia de cursos profissionais da área de Ciência da Informação. Tal proposta se completou com outro documento, publicado na revista em 2010, trazendo a fundamentação do curso de graduação em Museologia. Completou-se, assim, um amplo projeto, levado a termo por mais de dez anos, de reformulação da graduação da Escola de Ciência da Informação da UFMG em torno de um tronco comum de disciplinas da área de Ciência da Informação e as formações profissionais em Arquivologia, Biblioteconomia e Museologia.

$\mathrm{O}$ ano de 2010 foi rico em outras novidades, como o pioneirismo de PCI na área ao publicar num periódico científico um registro audiovisual, no caso, a conferência proferida por Rafael Capurro na Escola, no início do ano. Quatro meses depois, foi publicada também uma entrevista feita com este pensador, na ocasião da mesma visita. Ao final do ano, foi publicado ainda um suplemento com textos apresentados no II Encontro de Estudos e Pesquisa em Catalogação.

Por fim, também em 2010 foi publicado outro número especial, relativo aos 60 anos da Escola. Foram realizadas entrevistas com todos os ex-diretores da ECI, convertendo a edição num importantíssimo registro histórico da evolução da instituição e da área ao longo de seis décadas.

Igualmente, deve-se acrescentar a tudo o que foi publicado em PCI, a maneira como a revista foi conduzida até o momento, com sua periodicidade sempre rigorosamente cumprida, sua qualidade sempre garantida, com a atuação de pareceristas de reconhecida relevância nos âmbitos nacional e internacional, e a manutenção do conceito QUALIS sempre no topo da avaliação dos periódicos nacionais da área. 
Para coroar este auspicioso percurso anunciamos agora, com muita satisfação, que, a partir de 2011, PCI passará a ter periodicidade trimestral. Esta decisão do Conselho Editorial sinaliza para a importância crescente da criação de mais espaço para a divulgação e disseminação da produção científica de qualidade da área - e do papel que Perspectivas em Ciência da Informação, nos últimos 15 anos, vem cumprindo nessa tarefa.

Carlos Alberto Ávila de Araújo; Jorge Tadeu de Ramos Neves Equipe Editorial da revista Perspectivas em Ciência da Informação 